DOI: https://doi.org/10.24127/ajpm.v10i4.3996

\title{
ANALISIS KEMAMPUAN PEMECAHAN MASALAH MATEMATIS DITINJAU DARI KEPERCAYAAN DIRI
}

\author{
Andi Mariani Ramlan ${ }^{1 *}$, Hermayani ${ }^{2}$, Jahring $^{3}$ \\ ${ }^{1 * 2,3}$ Universitas Sembilanbelas November Kolaka, Kolaka, Indonesia \\ *Corresponding author. Jl. Pemuda No. 339, 93517, Kolaka, Indonesia. \\ E-mail: $\quad$ marianiramlan@ gmail.com ${ }^{1 *}$ \\ hermayani77c@gmail.com $\left.^{2}\right)$ \\ jahring.usn@gmail.com ${ }^{3}$
}

Received 16 July 2021; Received in revised form 12 September 2021; Accepted 15 December 2021

\begin{abstract}
Abstrak
Kemampuan pemecahan masalah matematis dan kepercayaan diri siswa masih belum optimal, perlu dikaji. Penelitian ini bertujuan mendekripsikan kemampuan pemecahan masalah matematis siswa kelas IX SMP Negeri 1 Baula ditinjau dari kepercayaan diri. Jenis penelitian ini adalah kualitatif. Subjek penelitian terdiri dari 56 siswa kelas IX SMP Negeri 1 Baula. Instrumen berupa angket kepercayaan diri (18 butir pernyataan), 3 butir soal tes kemampuan pemecahan masalah matematis, serta pedoman wawancara. Analisis data meliputi data reduksi, penyajian data dan penarikan kesimpulan. Hasil penelitian menunjukkan bahwa; 1) kepercayaan diri siswa dari 56 siswa terdiri dari, kepercayaan diri tinggi (6 siswa), sedang (24 siswa), dan rendah (26 siswa); 2) kemampuan pemecahan masalah kategori tinggi ( 5 siswa), kategori sedang ( 24 siswa), dan kategori rendah (27 siswa); dan 3) kepercayaan diri tinggi dengan kemampuan pemecahan masalah tinggi, siswa mampu memenuhi keempat indikator kemampuan pemecahan masalah. Kepercayaan diri sedang dengan kemampuan pemecahan masalah sedang, siswa kurang mampu dalam memenuhi keempat indikator kemampuan pemecahan masalah. Sedangkan efikasi diri rendah dengan kemampuan pemecahan masalah rendah, siswa tidak mampu memenuhi keempat indikator kemampuan pemecahan masalah. Sehingga disimpulkan bahwa semakin tinggi kepercayaan diri siswa akan semakin mudah dalam menyelesaikan masalah. Sebaliknya semakin rendah kepercayaan diri siswa akan semakin sulit dalam menyelesaikan masalah.
\end{abstract}

Kata kunci: Kemampuan pemecahan masalah; kepercayaan diri.

\begin{abstract}
Mathematical problem solving abilities and students' self-efficacy are still not optimal, so they need to be studied. This study aimed to describe the mathematical problem solving ability of class IX students of SMP Negeri 1 Baula in terms of self-efficacy. The type of this research was qualitative. The research subjects were 56 students of class IX SMP Negeri 1 Baula. The instruments were in the form of a self-efficacy questionnaire (18 statement items), 3 test questions of mathematical problem solving abilities, and interview guidelines. Data analysis covered data reduction, data presentation and drawing conclusions. There were three findings in this study as follows. Firstly, students' self-efficacy from 56 students consisted of high self-efficacy (6 students), medium (24 students), and low (26 students). Secondly, the number of students whose problem solving ability were being measured was in high category (5 students), medium category (24 students), and low category (27 students). And lastly, the students with high self-efficacy and high problem solving ability were able to meet the four indicators of problem solving ability. The students with moderate self-efficacy and moderate problemsolving abilities were less able to meet the four indicators of problem-solving abilities. While the students with low self-efficacy and low problem solving ability were not able to meet the four indicators of problem solving ability. So it can be concluded that the higher the students' self-efficacy is, the easier the students solve the problems. On the other hand, the lower the student's self-efficacy is, the more difficult the students solve the problems.
\end{abstract}

Keywords: Problem solving ability; self-efficacy.

This is an open access article under the Creative Commons Attribution 4.0 International License 
DOI: https://doi.org/10.24127/ajpm.v10i4.3996

\section{PENDAHULUAN}

Pemecahan masalah adalah suatu proses untuk mengatasi berbagai kesulitan dalam mencapai suatu tujuan. Siswa dalam pembelajaran matematika, harus memiliki kemampuan pemecahan masalah (Sumartini, 2018). Kemampuan pemecahan masalah merupakan salah satu bentuk kemampuan berpikir tingkat tinggi (Saputra et al., 2020). Pembelajaran harus menjadi lingkungan yang dapat melibatkan siswa secara aktif dalam kegiatan pembelajaran matematika, agar kemampuan berpikir tingkat tinggi berkembang (Suryati et al., 2013).

Kemampuan pemecahan masalah harus dicapai siswa sebagai salah satu tujuan dalam pembelajaran matematika. Dimana secara sadar ataupun tidak, setiap hari kita dihadapkan dengan berbagai permasalahan yang menuntut kemampuan pemecahan masalah. (Utami \& Wutsqa, 2017)

Menjalani kehidupan umumnya kita dihadapkan dengan masalah, jika cara atau suatu strategi tidak berhasil maka sebaiknya mencoba cara yang lain atau strategi berbeda. Siswa dalam menyelesaikan masalah perlu dilatih untuk mampu bersikap responsif, peka dengan lingkungan sekitar, dan mampu mengambil keputusan. Sehingga ketika siswa mampu menyelesaikan masalah artinya siswa mampu menerapkan strategi yang sesuai, tanggap dengan lingkungan, dan keputusan tepat. Sejalan dengan penelitian sebelumnya yang menyimpulkan bahwa suatu tingkat aktivitas intelektual yang tinggi, dimana siswa didorong dan diberi kesempatan seluas-luasnya untuk berinisiatif dan berpikir sistematis dalam menghadapi suatu masalah dengan menerapkan pengetahuan sebelumnya (Somawati, 2018).
Proses dalam mengembangkan kemampuan pemecahan masalah melalui latihan membuat keputusan dan kesimpulan berbagai permasalahan, sesuai pemikiran logis, rasional, kritis, cermat, jujur, efisien serta efektif. Sehingga dari proses itu, diharapkan siswa mampu menggunakan kemampuan pemecahan masalah di kehidupan kesehariannya, mempelajari berbagai ilmu pengetahuan untuk aktivitas bernalar, keterampilan penerapan matematika, serta pembentukan kepercayaan diri siswa (Jatisunda, 2017).

Pemecahan masalah matematika adalah salah satu hal sulit atau tergolong rendah bagi sebagian besar siswa mulai tingkat dasar dan perguruan tinggi (Tahir dan Kurniawan, 2020). Siswa tergolong rendah pada indikator membuat model matematik dari masalah sehari-hari. Siswa kesulitan pada indikator ini karena belum terbiasa dengan soal tersebut. Di samping itu banyak siswa kurang teliti dalam perhitungan (Aisyah et al., 2018). Siswa biasanya hanya menghapal konsep matematika tetapi kurang mampu dalam menggunakan konsep matematika untuk memecahkan masalah matematika (Pratiwi et al., 2019), (Rahayu \& Afriansyah, 2015).

Kemampuan pemecahan masalah matematis perlu didukung dengan sikap percaya diri, sehingga mampu menghadapi tantangan dalam kehidupan. Menurut (Jatisunda, 2017) kepercayaan diri adalah salah satu faktor penting yang menentukan prestasi matematika siswa khususnya melaksanakan tugas-tugas dalam bentuk soal-soal pemecahan masalah matematika yang tampak bahwa ada hubungan positif serta saling mendukung antara kemampuan pemecahan masalah dan kepercayaan diri. Jika siswa memiliki kepercayaan 
diri tinggi pada umumnya kemampuan pemecahan masalah matematis juga baik. Self-efficacy juga diartikan sebagai kepercayaan atau keyakinan siswa dalam menyelesaikan tugas-tugas yang diberikan, dalam situasi dan kondisi tertentu mampu mengatasi rintangan dan mencapai tujuan. Selain itu (Utami \& Wutsqa, 2017) mengemukakan terkait keyakinan siswa dalam pemecahan masalah dapat mempengaruhi hasil belajarnya.

Berdasarkan observasi awal dan wawancara pada guru matematika kelas IX di SMP Negeri 1 Baula menunjukkan belum optimalnya kemampuan pemecahan masalah matematis siswa. Terlihat dari hasil tugas siswa dari guru mata pelajaran matematika. Siswa kesulitan menyelesaikan masalah matematika secara baik. Beberapa siswa mampu mengidentifikasi unsur-unsur yang ditanyakan, diketahui, tetapi masih ada juga yang bingung menentukan rumus atau metode, serta strategi dalam menyelesaikannya. Penyebab rendahnya kemampuan pemecahan masalah diantaranya pembelajaran yang dilakukan, dimana siswa kurang memperhatikan guru saat mengajar, dan tidak sedikit siswa yang lebih menghafal tipe soal yang diberikan, sehingga saat siswa diberikan soal dengan modifikasi lain, maka siswa masih kesulitan dalam menyelesaikannya. Terlihat dari cara siswa menjawab soal.

Banyak siswa mengalami kesulitan belajar matematika. Siswa menganggap matematika merupakan pelajaran sulit yang memerlukan pemikiran keras dan otak cerdas. Hal ini mengakibatkan siswa tidak percaya diri dalam belajar. Mereka tidak mau mencoba mengerjakan soal dari guru, merasa tidak bisa sebelum mencoba sehingga cenderung pasif (Nasruddin dan Jahring, 2019). Kepercayaan diri siswa lemah mempengaruhi kemampuan pemecahan masalah. Sebagaimana dikemukakan (Askar et al., 2016) orang memiliki kepercayaan diri tinggi dapat menyelesaikan permasalahan dengan baik. Sedangkan siswa yang kepercayaan dirinya rendah, mengalami kesulitan menyelesaikan masalah matematika. Selain itu (Sholihah et al., 2020) mengemukakan kepercayaan diri menjadi bagian yang sangat penting dalam pemecahan masalah matematis peserta didik. Kepercayaan diri perlu diperhatikan sehingga siswa benar-benar baik memanfaatkan pengetahuannya dalam memecahkan masalah tanpa ragu dan takut mengalami kesalahan (Asdar et al., 2015). Di sisi lain bila guru mengajar terkait pemecahan masalah matematika tanpa memperhatikan kepercayaan diri siswa, maka siswa dapat mengalami kesalahan strategi dan ketidakmampuan menyelesaikan masalah. Kepercayaan diri perlu diperhatikan agar siswa tidak ragu dan benar-benar maksimal dalam memanfaatkan pengetahuannya (Askar et al., 2016).

Berdasarkan uraian secara teoritis, kemampuan pemecahan masalah dan kepercayaan diri mempunyai keterkaitan yang berperan penting untuk mencapai tujuan dan keberhasilan dalam pembelajaran matematika. Belum ada penelitian serupa di kabupaten Kolaka khususnya kecamatan Baula saat pandemik. Hal ini mendasari keharusan untuk melakukan penelitian terkait kemampuan pemecahan masalah dan kepercayaan diri siswa di kabupataten Kolaka tepatnya di SMPN 1 Baula. Diharapkan penelitan ini dapat memberi informasi terkait kemampuan pemecahan masalah matematika dan kepercayaan diri siswa, agar dapat meningkatkan kualitas pembelajaran serta menjadi solusi pemecahan masalah 
matematika khususnya pada masa pandemik. Metode penelitian didasarkan pada filsafat postpositivisme yang disebut metode penelitian naturalistik sebab dilakukan pada kondisi alamiah. Hal ini bersesuaian dengan penelitian survei di SMP Negeri Ciamis (Utami \& Wutsqa, 2017) dan juga penelitian yang menggunakan metode survei teknik analisis korelasional Jatisunda (2017).

Solusi diberikan setelah melakukan kajian terkait kemampuan pemecahan masalah matematika ditinjau dari kepercayaan diri yakni menganalisis lebih lanjut penyebab kesulitan siswa dengan kepercayaan diri sedang dan rendah agar bisa lebih baik dalam menyelesaikan permasalahan matematika. Menurut (Sulistiyorini \& Setyaningsih, 2016) guru sebaiknya dapat mengambil tindakan tepat dalam peningkatan kemampuan pemecahan masalah matematika khususnya dan masalah dalam kehidupan sehari-hari pada umumnya. Selain itu (Aristiani, 2016) mengemukakan bahwa rasa percaya diri dapat tertanam dengan menumbuhkan pembiasaan sikap berani bersosialisasi baik dalam kelas maupun luar kelas serta di lingkungan sekolah dalam kehiduan sehari-hari, oleh karena itu percaya diri termasuk hal yang harus dimiliki siswa. Tujuan penelitian diantaranya untuk mengetahui: 1) kepercayaan diri siswa kelas IX SMP Negeri 1 Baula; 2) kemampuan pemecahan masalah matematis siswa kelas IX SMP Negeri 1 Baula; 3) deskripsi kemampuan pemecahan masalah matematis ditinjau dari kepercayaan diri siswa kelas IX SMP Negeri 1 Baula.

\section{METODE PENELITIAN}

Penelitian ini merupakan penelitian deskriptif dengan pendekatan kualitatif untuk mengetahui gambaran kenyataan dari kejadian yang diteliti. Metode penelitian kualitatif dikemukakan (Sugiyono, 2019) sebagai metode penelitian berdasarkan filsafat postpositivisme, untuk meneliti pada kondisi alamiah, dimana peneliti adalah instrumen kunci. Selain itu, berusaha mengetahui lebih rinci kemampuan pemecahan masalah matematis berdasarkan kepercayaan diri siswa.

Subjek penelitian berjumlah 56 orang siswa kelas IX SMP Negeri 1 Baula tahun pelajaran 2020/2021. Materi yang diteliti adalah persamaan kuadrat. Selanjutnya berdasarkan angket kepercayaan diri, dipilih beberapa subjek untuk dilakukan wawancara terkait soal tes yang telah diberikan. Adapun subjek wawancara dipilih dengan teknik purposive sampling berdasarkan masing-masing kategori (tinggi, sedang, dan rendah) kemudian didiskusikan dengan guru matematika.

Instrumen penelitian berupa tes kemampuan pemecahan masalah matematis, angket kepercayaan diri, serta pedoman wawancara. Tes digunakan berbentuk uraian dan berjumlah 3 butir soal. Tes memuat indikator kemampuan pemecahan masalah matematis. Angket untuk memperoleh data kepercayaan diri siswa dan pedoman wawancara sebagai teknik pendukung disamping tes untuk mendapat gambaran kemampuan pemecahan masalah matematis siswa.

Prosedur penelitian diantaranya: (1) melakukan kunjungan ke lokasi penelitian sekaligus melakukan observasi awal; (2) menyiapkan instrumen yang dibutuhkan seperti, instrumen tes kemampuan pemecahan masalah, angket kepercayaan diri, serta pedoman wawancara yang akan diajukan dan yang ingin diketahui dari kegiatan wawancara yang nantinya akan dilakukan; (3) uji coba instrumen tes 
kemampuan pemecahan masalah serta angket kepercayaan diri; (4) pemberian atau pelaksanaan tes kemampuan pemecahan masalah dan pengisisan angket kepercayaan diri siswa; (5) wawancara kemampuan pemecahan masalah matematis siswa; (6) analisis hasil tes kemampuan pemecahan masalah matematis dan angket kepercayaan diri; (7) mendeskripsikan kemampuan pemecahan masalah matematis siswa berdasarkan angket kepercayaan diri dengan hasil wawancara.

Data yang diperoleh melalui tes tertulis, angket, dan wawancara selanjutnya dilakukan triangulasi untuk mngecek keabsahan data. Penelitian ini menggunakan analisis data deskripsi kualitatif menurut Miles dan Huberman yang meliputi data reduksi, penyajian data dan penarikan kesimpulan dikemukakan (Sugiyono, 2017) yakni:

1. Reduksi Data (Data Reduction)

Reduksi data yakni merangkum data angket kepercayaan diri siswa selanjutnya dikelompokkan berdasarkan pengkategorian (tinggi, sedang, dan redah). Dan data kemampuan pemecahan masalah matematis dikelompokkan dengan kepercayaan diri tinggi, sedang, dan rendah.

\section{Penyajian Data (Data Display)}

Penyajian data berupa gambaran jawaban soal kemampuan pemecahan masalah matematis siswa yang selanjutnya dideskripsikan dalam uraian singkat. Kemudian wawancara dalam bentuk deskripsi uraian singkat proses pemecahan masalah matematis siswa dalam bentuk tanya jawab.

\section{Penarikan Kesimpulan (Conclussion Drawing or Verification) \\ Penarikan kesimpulan dengan} membandingkan hasil analisis tes siswa dan wawancara, serta teori-teori berkaitan dengan kemampuan pemecahan masalah matematis. Selanjutnya menyimpulkan dan mendeskripsikan kemampuan pemecahan masalah matematis berdasarkan kepercayaan diri.

\section{HASIL DAN PEMBAHASAN}

Berdasarkan hasil analisis angket kepercayaan diri yang diisi oleh 56 siswa, diperoleh nilai yang cukup bervariasi. Adapun data distribusi siswa berdasarkan kepercayaan diri yakni pada Tabel 1.

Tabel 1. Data kepercayaan diri kelas IX SMPN 1 Baula

\begin{tabular}{clc}
\hline No & Kepercayaan Diri & Frekuensi \\
\hline 1 & Tinggi $(80 \leq \mathrm{x} \leq 100)$ & 6 \\
2 & Sedang $(60 \leq \mathrm{x}<80)$ & 24 \\
3 & Rendah $(0 \leq \mathrm{x}<60)$ & 26 \\
\hline & Jumlah & $\mathbf{5 6}$ \\
\hline
\end{tabular}

Berdasarkan hasil tes kemampuan pemecahan masalah matematis dari 56 siswa kelas IX SMPN 1 Baula diklasifikasikan berdasarkan kategori tinggi, sedang dan rendah. Adapun data tersebut pada Tabel 2 .

Tabel 2. Data kemampuan pemecahan masalah matematis kelas IX SMPN 1 Baula

\begin{tabular}{clc}
\hline No & $\begin{array}{c}\text { Kemampuan Pemecahan } \\
\text { Masalah }\end{array}$ & Frekuensi \\
\hline 1 & Tinggi $($ Nilai $\geq 75)$ & 6 \\
2 & Sedang $(60 \leq$ Nilai $<75)$ & 24 \\
3 & Rendah $($ Nilai $<60)$ & 26 \\
\hline & Jumlah & $\mathbf{5 6}$ \\
\hline
\end{tabular}

Selanjutnya dari hasil analisis tes dikategorikan tiap indikator untuk mengetahui rata-rata indikator kemampuan pemecahan masalah matematis yakni pada Tabel 3 . 
DOI: https://doi.org/10.24127/ajpm.v10i4.3996

Tabel 3. Rata-rata kemampuan pemecahan masalah matematis kelas IX SMPN 1 Baula

\begin{tabular}{llc}
\hline No & \multicolumn{1}{c}{ Indikator Kemampuan Pemecahan Masalah } & Rata-rata Indikator \\
& Matematis & \\
\hline 1 & Memahami masalah & 55,06 \\
2 & Merencanakan masalah & 54,96 \\
3 & Menyelesaikan masalah & 59,72 \\
4 & Memberi kesimpulan & 41,96 \\
\hline Rata-rata Keseluruhan & $\mathbf{5 2 , 9 3}$
\end{tabular}

Berdasarkan tabel 3 kemampuan pemecahan masalah matematis siswa kelas IX SMPN 1 Baula adalah rata-rata 52,93 berada pada kriteria rendah dengan masing-masing persentase indikator memahami masalah 5,506\%, merencanakan masalah 5,496\%, menyelesaikan masalah $5,972 \%$, dan memberi kesimpulan 4,196\%. Ada 27 siswa kemampuan pemecahan masalah rendah dari 56 siswa. Dari keseluruhan siswa kelas IX yang menjadi subjek penelitian diambil tiga orang siswa (S1S3) yang mewakili masing-masing kriteria kemampuan pemecahan masalah matematis ditinjau dari kepercayaan diri. Adapun data dari subjek penelitian yakni subjek S1 (kepercayaan diri tinggi dan kemampuan pemecahan masalah matematis tinggi), S2 (kepercayaan diri dan kemampuan pemecahan masalah matematis sedang), S3 (kepercayaan diri dan kemampuan pemecahan masalah matematis rendah).

\section{Analisis Kemampuan Pemecahan Masalah Matematis S1}

Pembahasan pertama mengenai indikator memahami masalah soal nomor 1 disajikan pada Gambar 1.

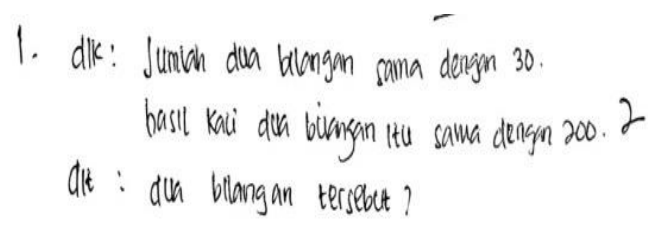

Gambar 1. Pekerjaan S1 nomor 1 (a)
Pada gambar 1 memperlihatkan bahwa S1 mampu memahami masalah dengan menuliskan permasalahan dan fakta yang ada pada soal tersebut dengan tepat. Soal nomor 2 pada Gambar 2.

\section{2. dit: Pandang den kbar tanah tersebut?}

Gambar 2. Pekerjaan S1 nomor 2 (a)

Gambar 2 memperlihatkan bahwa S1 kurang mampu memahami masalah. Selanjutnya terdapat hasil pekerjaan S1 untuk soal nomor 3(a) disajikan pada Gambar 3.

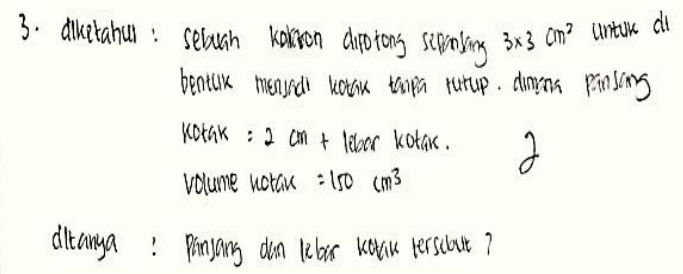

Gambar 3. Pekerjaan S1 nomor 3 (a)

Gambar 3 memperlihatkan bahwa S1 mampu menuliskan permasalahan dan fakta yang diketahui dalam soal secara benar. Berdasarkan hasil analisis data pada indikator memahami masalah soal nomor 1, 2, dan 3 disimpulkan S1 dapat merumuskan permasalahan serta fakta yang diketahui pada soal.

Soal nomor 1 pada Gambar 4 untuk indikator merencanakan masalah.

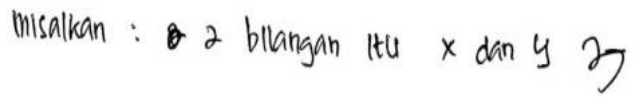

Gambar 4. Pekerjaan S1 nomor 1 (b) 
DOI: https://doi.org/10.24127/ajpm.v10i4.3996

Gambar 4 memperlihatkan bahwa S1 dapat menuliskan strategi dari soal dengan tepat. Soal nomor 2 pada Gambar 5.

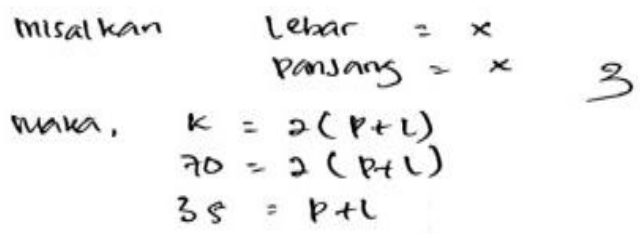

Gambar 5. Pekerjaan S1 Nomor 2 (b)

Gambar 5 memperlihatkan bahwa S1 mampu menuliskan strategi dari soal dengan tepat.

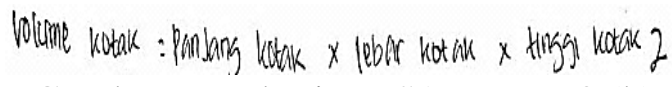
Gambar 6. Pekerjaan S1 Nomor 3 (b)

Gambar 6 memperlihatkan bahwa S1 mampu menuliskan strategi dari soal dengan tepat. Berdasarkan hasil dari analisis data pada indikator merencanakan masalah soal nomor 1, 2, dan 3 disimpulkan S1 mampu merencanakan strategi penyelesaian masalah dari soal.

Soal nomor 1 pada Gambar 7 untuk indikator menyelesaikan masalah. Gambar 7 memperlihatkan bahwa S1 mampu menyelesaikan permasalahan dari soal dengan tepat.

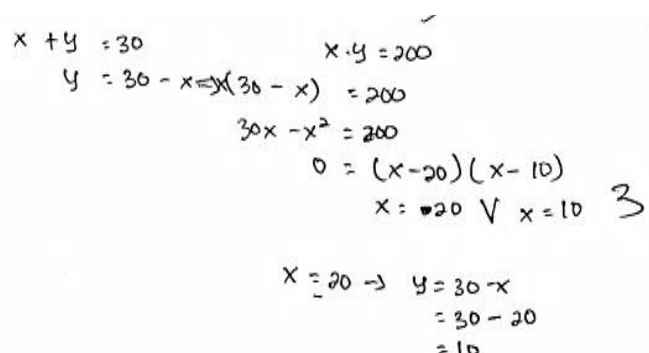

Gambar 7. Pekerjaan S1 Nomor 1 (c)

Gambar $8 \quad$ memperlihatkan
bahwa S1 mampu menyelesaikan
permasalahan dari soal dengan tepat.

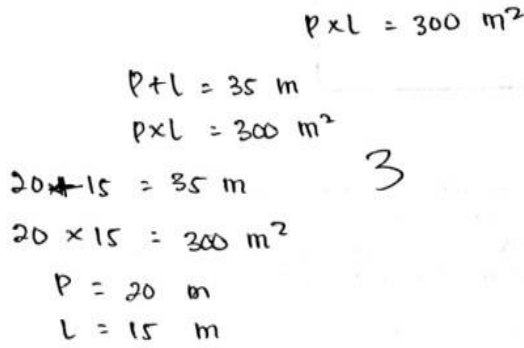

Gambar 8. Pekerjaan S1 Nomor 2 (c)

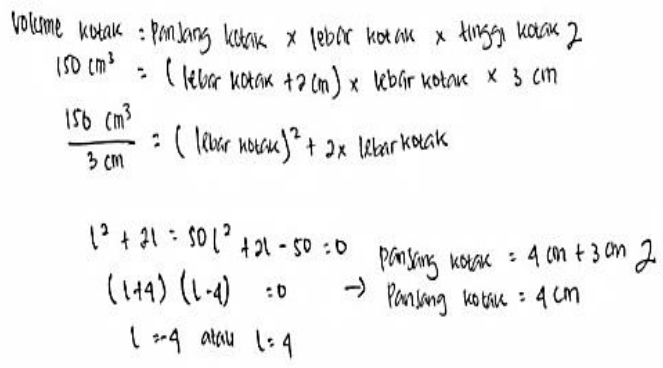

Gambar 9. Pekerjaan S1 Nomor 3 (c)

Gambar 9 memperlihatkan bahwa S1 tidak mampu menyelesaikan masalah dari soal tersebut dengan tepat. Berdasarkan hasil dari analisis data yang dilakukan terhadap semua indikator kemampuan pemecahan masalah matematis pada soal nomor 1, 2, dan 3 disimpulkan bahwa S1 kurang mampu menyelesaikan permasalahan yang terdapat dalam soal.

Soal nomor 1 gambar 10 untuk indikator mengecek kembali dan memberi kesimpulan.

* Jadi, hasil perhitungan diatas, kedva bilangan tersebut adalah 10 dan $20 \quad 2$

Gambar 10. Pekerjaan S1 Nomor 1 (d)

Gambar 10 menunjukkan bahwa S1 mampu melaksanakan indikator mengecek kembali dan memberi kesimpulan dari soal dengan tepat.

Jad, bansang persegl pansang tanah terebut adalan $20 \mathrm{~m}$ dan lebar perege pankang tanch tersebat adxilah $l=15 \mathrm{~m} 2$

Gambar 11. Pekerjaan S1 nomor 2 (d) 
DOI: https://doi.org/10.24127/ajpm.v10i4.3996

Gambar 11 memperlihatkan S1 mampu melaksanakan indikator mengecek kembali dan memberi kesimpulan dari soal tersebut dengan tepat.

\section{Jadl, kebar notak tersebut adakih $4 \mathrm{~cm}$ ।}

Gambar 12. Pekerjaan S1 Nomor 3 (d)

Gambar 12 menunjukkan bahwa S1 mampu melaksanakan indikator mengecek kembali dan memberi kesimpulan dari soal tersebut dengan tepat. Berdasarkan hasil analisis data yang dilakukan terhadap semua indikator kemampuan pemecahan masalah matematis pada soal nomor 1 , 2, dan 3 dapat disimpulkan bahwa S1 kurang mampu menyelesaikan permasalahan yang terdapat dalam soal.

\section{Analisis Kemampuan Pemecahan Masalah Matematis S2}

Indikator pada soal nomor 1 memahami masalah dapat dilihat pada Gambar 13.

\section{1. dlk: Junche dula blungan sama dengan 30.

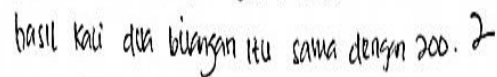 dit: athe blangan tersebt?}

Gambar 13. Pekerjaan S2 Nomor 1 (a)

Gambar 13 memperlihatkan bahwa S2 mampu memahami masalah dengan menuliskan permasalahan dan fakta pada soal tesebut dengan tepat. S2 pada soal nomor 2 tidak menuliskan rencana strategi penyelesaian masalah. S2 tidak menuliskan apa yang diketahui dan ditanyakan dalam soal sehingga S2 tidak mampu menuliskan permasalahan dan fakta yang ada pada soal nomor 3 .

Berdasarkan hasil analisis data yang dilakukan terhadap indikator memahami masalah pada soal nomor 1 ,
2, dan 3 dapat disimpulkan bahwa bahwa S2 tidak mampu merumuskan permasalahan serta fakta yang diketahui pada soal.

Indikator merencanakan masalah, S2 tidak mampu menuliskan strategi atau perencanaan dalam menyelesaikan masalah pada soal nomor 1 dan 2. S2 mampu menuliskan strategi dari soal dengan tepat pada soal nomor 3 .

Berdasarkan dari hasil analisis data yang dilakukan terhadap indikator merencanakan masalah pada soal nomor 1, 2, dan 3 dapat disimpulkan bahwa S2 kurang mampu merencanakan strategi penyelesaian masalah dari soal.

Indikator menyelesaikan masalah pada soal nomor 1, S2 mampu menyelesaikan permasalahan dari soal dengan tepat. Pada soal nomor 2, S2 mampu menyelesaikan permasalahan dari soal dengan tepat. Soal nomor 3 dapat dilihat pada Gambar 14.

$$
\begin{aligned}
& \text { 3. Vocumo }=p \times 1 \times 6=2 \\
& 105=p^{*}(p-2)^{*} 3 \\
& \text { 105 }=3 p^{\wedge}=6 p \\
& p^{1} 2-2 p-35=0 . p=7 \\
& \text { Panjang acas kotak }=7 \mathrm{~cm} 2 \\
& \text { lobar kotak }=5 \mathrm{~cm} \\
& \text { finggi }
\end{aligned}
$$

Gambar 14. Pekerjaan S2 Nomor 3 (c)

Gambar 14 memperlihatkan bahwa S2 mampu menyelesaikan masalah dari soal tersebut walaupun masih ada yang kurang lengkap dalam proses penyelesaiannya. Berdasarkan hasil analisis data pada indikator menyelesaikan masalah pada soal nomor 1, 2, dan 3 dapat disimpulkan bahwa S2 mampu menyelesaikan permasalahan dalam soal.

Indikator mengecek kembali dan memberi kesimpulan pada soal nomor 1, S2 mampu melaksanakan indikator mengecek kembali dan memberi 
kesimpulan dari soal tersebut dengan tepat. S2 mampu melaksanakan indikator mengecek kembali dan memberi kesimpulan dari soal tersebut dengan tepat pada soal nomor 2. S2 tidak mampu menuliskan kesimpulan pada soal nomor 3 ,.

Berdasarkan hasil analisis data yang dilakukan terhadap indikator mengecek kembali dan memberi kesimpulan pada soal nomor 1, 2, dan 3 dapat disimpulkan bahwa S2 kurang mampu menyelesaikan permasalahan yang terdapat dalam soal.

\section{Analisis Kemampuan Pemecahan Masalah Matematis S3}

Indikator memahami masalah pada soal nomor 1 dapat dilihat pada Gambar 15.

\section{1. d kehahu Jumlah dua bilagan Sama degan 30}

Gambar 15. Pekerjaan S3 Nomor 1(a)

Gambar 15 memperlihatkan bahwa S3 mampu menuliskan yang diketahui tetapi tidak menuliskan yang ditanyakan dalam soal. S3 tidak menuliskan apa yang diketahui maupun yang ditanyakan pada soal nomor 2 dan 3. Selain itu S3 tidak mampu menuliskan permasalahan dan fakta yang ada pada soal nomor 3 .

Berdasarkan hasil analisis data yang dilakukan terhadap indikator memahami masalah pada soal nomor 1 , 2, dan 3 dapat disimpulkan bahwa bahwa S3 tidak mampu merumuskan permasalahan serta fakta yang diketahui pada soal.

Indikator merencanakan masalah S3 tidak menuliskan strategi atau perencanaan dalam menyelesaikan masalah pada soal nomor 1, 2, dan 3 .

Berdasarkan dari hasil analisis data yang dilakukan terhadap indikator merencanakan masalah pada soal nomor
1, 2, dan 3 dapat disimpulkan bahwa S3 tidak mampu merencanakan strategi penyelesaian masalah dari soal.

Indikator soal nomor 1 menyelesaikan masalah dapat dilihat pada Gambar 16.

$$
\begin{aligned}
& 30 \times 200=6.000 \\
& 30 \times 30=900 \\
& 200 \times 200=40.000
\end{aligned}
$$

Gambar 16. Pekerjaan S3 Nomor 1(c)

Gambar 16 memperlihatkan bahwa S3 tidak mampu menyelesaikan permasalahan dari soal nomor 1 dengan benar.

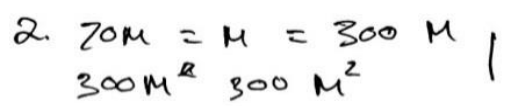

Gambar 17. Pekerjaan S3 Nomor 2(a)

Gambar 17 memperlihatkan bahwa S3 tidak mampu menyelesaikan permasalahan dari soal nomor 2 dengan benar.

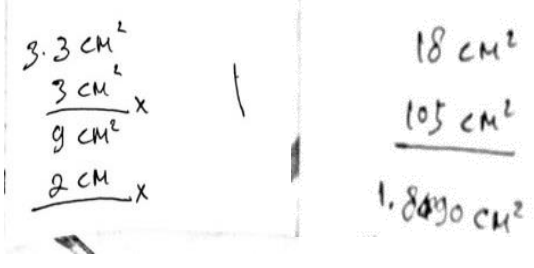

Gambar 18. Pekerjaan S3 Nomor 1(c)

Gambar 18 memperlihatkan bahwa S3 dari soal nomor 3 tidak mampu menyelesaikan permasalahan dengan benar. Berdasarkan hasil dari analisis data terhadap indikator menyelesaikan masalah pada soal nomor 1, 2, dan 3 disimpulkan bahwa S3 tidak mampu menyelesaikan permasalahan dalam soal dengan tepat. Indikator soal nomor 1 mengecek kembali dan memberi kesimpulan dapat dilihat pada Gambar 19. 
DOI: https://doi.org/10.24127/ajpm.v10i4.3996

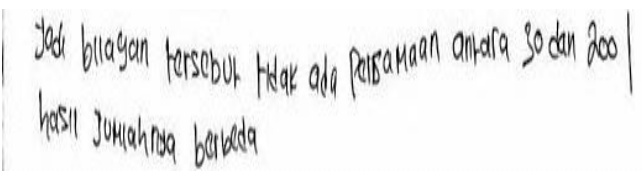

Gambar 19. Pekerjaan S3 Nomor 1(d)

Pada gambar 19 memperlihatkan bahwa S3 mampu memberikan kesimpulan dari soal tersebut tetapi kurang tepat.

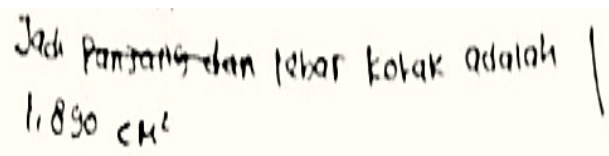

Gambar 20. Pekerjaan S3 Nomor 2(d)

Gambar 20 memperlihatkan bahwa S3 tidak mampu mengecek kembali jawaban yang telah diperoleh dan memberikan kesimpulan dari jawaban yang didapat kurang tepat.

Jad Panjang dan lebar persegi Panjang terssbuh odalah $300 \mathrm{~K}$

Gambar 21. Pekerjaan S3 Nomor 1(d)

Gambar 21 memperlihatkan bahwa S3 tidak mampu mengecek kembali jawaban yang telah didapatkan dan memberikan kesimpulan dari jawaban yang didapat kurang tepat. Berdasarkan hasil analisis data terhadap indikator memeriksa kembali dan memberi kesimpulan soal nomor 1, 2, dan 3 disimpulkan bahwa S3 tidak dapat menyelesaikan permasalahan yang terdapat dalam soal.

Penelitian ini sejalan dengan penelitian (Jatisunda, 2017) yakni ada hubungan positif antara kemampuan pemecahan masalah dan kepercayaan diri siswa. Sedangkan dalam penelitian ini memberi informasi terkait siswa dengan kepercayaan diri tinggi mampu memenuhi keempat indikator kemampuan pemecahan masalah, kepercayaan diri sedang kurang mampu memenuhi keempat indikator kemampuan pemecahan masalah, dan kepercayaan diri rendah siswa tidak mampu memenuhi keempat indikator kemampuan pemecahan masalah matematis. Selain itu (Utami \& Wutsqa, 2017) bahwa hubungan kemampuan pemecahan masalah matematika dan kepercayaan diri siswa termasuk kategori sangat rendah, dimana pada penelitian ini menggunakan tiga kategori dengan rata-rata kemampuan pemecahan masalah matematis dan kepercayaan diri siswa berada pada kategori rendah. Sehingga perlu suatu cara untuk meningkatkan atau memperbaiki kemampuan pemecahan masalah ditinjau dari kepercayaan diri misalnya menerapkan model, strategi, pendekatan, maupun metode yang tepat agar siswa bisa berprestasi lebih unggul, serta melatihkan soal-soal kemampuan pemecahan masalah dalam pembelajaran di kelas maupun tugas terstruktur.

Hasil yang diperoleh demikian adanya sesuai kondisi di lapangan dan pada umumnya siswa dengan kepercayaan diri tinggi mampu menyelesaikan permasalahan matematika, sebaliknya untuk siswa dengan kepercayaan diri sedang maupun rendah tidak mampu secara maksimal menyelesaikan permasalahan matematika. Sehingga perlu pembiasaan dan perhatian serta penanganan cepat dan tepat setelah dilakukan kajian mendalam atau berdasarkan informasi awal siswa terkait kemampuan pemecahan masalah dan kepercayaan diri dapat dimanfaatkan secara efisien dalam mengatasi permasalahan. Selain kondisi pandemik menjadi faktor lain pembelajaran menjadi tidak maksimal, guru, siswa, orang tua, pemerhati pendidikan mempunyai andil dalam menyelesaikan permasalahan dalam pembelajaran khususnya matematika. 
DOI: https://doi.org/10.24127/ajpm.v10i4.3996

Kelebihan dari penelitian ini dapat memberi informasi awal sebagai data yang mewakili kondisi kemampuan pemecahan masalah dan kepercayaan diri siswa di SMP Baula, Subjek yang selanjutnya diwawancarai memberi informasi bermanfaat khususnya guru, siswa, peneliti, orag tua, dan pemerhati pendidikan lainnya. Sedangkan kekurangan masih kurang mampu menggeneralisasi kondisi sekolahsekolah di Kabupaten Kolaka.

Dampak dari penelitian ini setelah mendapatkan informasi terkait gambaran deskripsi kemampuan pemecahan masalah yang ditinjau berdasarkan kepercayaan diri dapat dijadikan data awal untuk mengatasi kesulitan yang dihadapi siswa sehingga penanganan akan lebih tepat.

\section{KESIMPULAN DAN SARAN}

Berdasarkan hasil analisis data dan pembahasan disimpulkan: 1) dari 56 siswa kelas IX SMPN 1 Baula, kepercayaan diri tinggi (6 siswa), sedang (24 siswa), dan rendah (26 siswa; 2) kemampuan pemecahan masalah matematis tinggi (5 siswa), sedang (24 siswa), dan rendah (26 siswa); 3) siswa yang memiliki kepercayaan diri tinggi mampu memenuhi keempat indikator kemampuan pemecahan masalah, kepercayaan diri sedang kurang mampu memenuhi keempat indikator kemampuan pemecahan masalah, dan siswa dengan kepercayaan diri rendah tidak mampu memenuhi keempat indikator kemampuan pemecahan masalah matematis. Sehingga kepercayaan diri siswa tinggi akan mudah menyelesaikan masalah. Sebaliknya jika kepercayaan diri rendah maka akan semakin sulit menyelesaikan suatu masalah.
Berdasarkan pembahasan dan kesimpulan, saran yang sekiranya bermanfaat antara lain: 1) diharapkan guru menggunakan model, strategi, pendekatan, maupun metode yang tepat agar dapat meningkatkan kepercayaan diri siswa sehingga kemampuan pemecahan masalah menjadi lebih baik. Guru perlu meningkatkan kemampuan pemecahan masalah matematis siswa secara rutin melatih siswa mengerjakan soal pemecahan masalah; 2) siswa harus yakin terhadap kemampuan dirinya ketika mengerjakan sal-soal yang berkaitan dengan kemampuan pemecahan masalah; 3) perlu diadakan penelitian lanjutan terkait kemampuan pemecahan masalah matematis siswa ditinjau dari kepercayaan diri.

\section{DAFTAR PUSTAKA}

Aisyah, P. N., Nuraini, N., Akbar, P., \& Yuliani, A. (2018). Analisis Hubungan Kemampuan Pemecahan Masalah Matematis dan Self Confidence Siswa Smp. Journal On Education, 1(1), 58-65.

Aristiani, R. (2016). Meningkatkan Percaya Diri Siswa Melalui Layanan Informasi Berbantuan Audiovisual. Jurnal Konseling Gusjigang, 2(2), 182-189. https://doi.org/10.24176/jkg.v2i2.7 17

Asdar, Arifin, S., \& Rahman, A. (2015). Profil Pemecahan Masalah Matematika Siswa Ditinjau dari Gaya Kognitif dan Efikasi Diri Pada Siswa Kelas VIII Unggulan SMPN 1 Watampone. Jurnal Daya Matematis, $3(1), \quad 20$. https://doi.org/10.26858/jds.v3i1.13 13

Askar, Rizal, M., \& Hamid, A. (2016). Profil Pemecahan Masalah Matematika Siswa SMP Kelas VII pada Materi Bangun Datar Ditinjau dari Tingkat Efikasi Diri. Jurnal Elektronik Pendidikan Matematika 
DOI: https://doi.org/10.24127/ajpm.v10i4.3996

Tadulako, 4(2), 314-325.

Jatisunda, M. G. (2017). Hubungan SelfEfficacy Siswa SMP dengan Kemampuan Pemecahan Masalah Matematis. Jurnal Theorems (The Original Research of Mathematics), 1(2), 24-30. http://www.jurnal.unma.ac.id/index .php/th/article/view/375

Nasruddin dan Jahring. (2019). Efektivitas Penerapan Model Pembelajaran Reciprocal Teaching dalam Meningkatkan Kemampuan Komunikasi Matematis Siswa. Jurnal.Unsulbar.Ac.Id/Saintifik, 5(1), 27-35.

Pratiwi, D., Suendarti, M., \& Hasbullah, H. (2019). Pengaruh Efikasi Diri dan Kemandirian Belajar terhadap Kemampuan Pemecahan Masalah Matematika. JKPM (Jurnal Kajian Pendidikan Matematika), 5(1), 1. https://doi.org/10.30998/jkpm.v5i1. 5083

Rahayu, D. V., \& Afriansyah, E. A. (2015). Matematik Siswa Melalui Model Pembelajaran Pelangi Matematika. Mosharafa: Jurnal Pendidikan Matematika, 5(1), 29$37 . \quad$ http://www.emosharafa.org/index.php/mosharafa /article/view/mv4n1_4/201

Saputra, R., Rosita, C. D., \& Maharani, A. (2020). Kemampuan Pemecahan Masalah Siswa Pada Topik Trigonometri. Jurnal Cendekia: Jurnal Pendidikan Matematika, 4(2), 857-869. https://doi.org/10.31004/cendekia.v $4 \mathrm{i} 2.312$

Sholihah, I., Munawwir, Z., \& Noervadila, I. (2020). Analisis Efikasi Diri dalam Pemecahan Masalah Matematis Peserta Didik Kelas XI MA Darul Ulum. Jurnal Pendidikan Dan Kewirausahaan, 8(1), 66-76. https://doi.org/10.47668/pkwu.v8i1. 69

Somawati, S. (2018). Peran Efikasi Diri
(Self Efficacy) terhadap Kemampuan Pemecahan Masalah Matematika. Jurnal Konseling Dan Pendidikan, 6(1), 39. https://doi.org/10.29210/118800

Sugiyono. (2017). Metodologi Penelitian Pendidikan (Pendekatan Kuantitatif, Kualitatif dan $R \& D)$. Alfabeta.

Sugiyono. (2019). Metode Penelitian Kuantitatif, Kombinasi, Kualitatif, $R \& D$ dan Penelitian Pendidikan. Alfabeta.

Sulistiyorini, \& Setyaningsih, N. (2016). Analisis Kesulitan Siswa dalam Pemecahan Masalah Soal Cerita Matematika Pada Siswa SMP. Seminar Nasional Pendidikan Matematika, 1-9.

Sumartini, T. S. (2018). Peningkatan Kemampuan Pemecahan Masalah Matematis Siswa melalui Pembelajaran Berbasis Masalah. Mosharafa: Jurnal Pendidikan Matematika, 5(2), 148-158. https://doi.org/10.31980/mosharafa. v5i2.270

Suryati, Masrukan, \& Wardono. (2013). Pengaruh Asesmen Kinerja Dalam Model Pembelajaran Arias Terhadap Kemampuan Pemecahan Masalah. Unnes Journal of Mathematics Education, 2(3). https://doi.org/10.15294/ujme.v2i3. 3360

Tahir dan Kurniawan, P. (2020). Penerapan Model Pembelajaran Penemuan Terbimbing Terhadap Peningkatan Kemampuan Pemecahan Masalah Matematis Mahasiswa. 9(4), 1059-1066.

Utami, R. W., \& Wutsqa, D. U. (2017). Analisis Kemampuan Pemecahan Masalah Matematika dan SelfEfficacy Siswa SMP Negeri di Kabupaten Ciamis. Jurnal Riset Pendidikan Matematika, 4(2), 166. https://doi.org/10.21831/jrpm.v4i2. 14897 